\begin{tabular}{|c|c|c|}
\hline Beitr. Ent. & Keltern & ISSN 0005-805X \\
\hline $\mathbf{6 2}(2012) 1$ & S. $207-224$ & 15.05 .2012 \\
\hline
\end{tabular}

\title{
On the taxonomy and natural history of Oxypoda brachyptera and O. tarda
}

\section{(Coleoptera: Staphylinidae: Aleocharinae)}

With 28 figures and 2 tables

VolKer Assing

Summary

Based on a revision of types and additional material, Oxypoda brachyptera (STEPHENs, 1832) and O. tarda SHARP, 1871, two species with a controversial and confusing taxonomic history, are regarded as distinct species, redescribed, and illustrated. A lectotype is designated for Oxypoda tarda. Numerous field studies conducted in northwestern Germany during the period from 1981 through 2001 yielded approximately 8,500 adult specimens of $O$. brachyptera and $O$. tarda. Based on these data, as well as on anatomical studies, the life histories of both species, including their seasonal activity, seasonal density, reproduction periods, duration of pre-imaginal development, and pupal emergence, are investigated. Both species are epigeically active from spring through autumn, develop without diapause, and hibernate in the adult stage. In contrast to Oxypoda tarda, which has only one generation per year, O. brachyptera is apparently bivoltine. Both species are generally found in open, unshaded biotopes. Nevertheless, regarding their respective habitats, they are distinctly segregated. While $O$. brachyptera was recorded from drier and wamer habitats on sandy or calcareous soils, $O$. tarda usually occurs in moist localities on heavier soils. Rarely, they were found to occur syntopically. Both species are wing-dimorphic, the macropterous morph being distinctly rarer than the micropterous morph; the dimorphism is not sex-related.

\section{Key words}

Coleoptera, Staphylinidae, Aleocharinae, Oxypodini, Oxypoda, West Palaearctic, taxonomy, ecology, lectotype designations, natural history, seasonal activity, seasonal density, oviposition, flight muscles, wing dimorphism

\section{Zusammenfassung}

Die Identität von Oxypoda brachyptera (STEPHens, 1832) und O.tarda SHARP, 1871 war in der Vergangenheit immer wieder Gegenstand kontroverser Sichtweisen; beide Arten wurden oft konfundiert. Eine Untersuchung der Typen und weiteren Materials ergab, dass es sich zweifelsfrei um verschiedene Arten handelt; sie werden redeskribiert und abgebildet. Für Oxypoda tarda wird ein Lectotypus designiert. Zahlreiche Freilanduntersuchungen, die in verschiedenen Biotopen Nordwestdeutschlands in der Zeit von 1981 bis 2001 durchgeführt wurden, ergaben eine Datenbasis von insgesamt annähernd 8500 Imagines von O. brachyptera und O. tarda. Auf dieser Grundlage sowie anhand anatomischer Untersuchungen wird die Phänologie beider Arten, einschließlich der saisonalen Aktivität, der saisonalen Dichte, Reproduktionsphasen, Dauer der Präimaginalentwicklung und Emergenz, geklärt. Beide Arten sind vom Frühjahr bis in den Spätherbst epigäisch aktiv, entwickeln sich ohne Diapause und überwintern im Adultstadium. Anders als Oxypoda tarda, für die nur eine Generation pro Jahr nachgewiesen wurde, ist $O$. brachyptera offenbar bivoltin. Beide Arten kommen in der Regel in unbewaldeten 
Biotopen vor. Trotzdem sind sie hinsichtlich ihrer Habitate deutlich gesondert. Während O. brachyptera trockenere und wärmere Lebensräume auf Sand- oder Kalkböden besiedelt, war $O$. tarda gewöhnlich in feuchteren Biotopen auf schwereren Böden vertreten. Selten wurden beide Arten syntop nachgewiesen. Sowohl $O$. brachyptera als auch $O$. tarda sind flügeldimorph; bei beiden ist die macroptere Morphe fast immer deutlich seltener als die brachyptere Morphe. Hinsichtlich dieses Dimorphismus wurden keine Unterschiede zwischen den Geschlechtern beobachtet.

\section{Introduction}

Oxypoda brachyptera (STEPhens, 1832) and O. tarda Sharp, 1871 have had a long history of taxonomic confusion. The original description of the former is based on specimens from two localities in England. Sharp (1871) described O. tarda from Scotland, stating that the species was distinguished from $O$. brachyptera by darker coloration, larger size, longer elytra, and shorter and finer antennae. However, $O$. tarda was regarded as either a synonym or a variety by most subsequent authors (e.g., Ganglbauer 1895, Bernhauer 1902, Bernhauer \& Scheerpeltz 1926, Joy 1932, Horion 1967, Pope 1977). In an article on some Central European Oxypoda species, LoHse (1970) stated that what had been recorded as O. difficilis Roubal, 1931 from Germany in fact referred to O. tarda, but had not studied the types of the latter. According to a key he published a few years later (LoHsE 1974), O. tarda and O. difficilis are distinguished from $O$. brachyptera by the denser punctation of the abdomen (particularly abdominal tergite VIII), the longer elytra, the weaker punctation of the pronotum, and the longer and more slender antennae. Apparently based on a personal communication by ZERCHE, LOHSE (1989) synonymised $O$. difficilis with $O$. brachyptera. In a contribution specifically dealing with the identities of $O$. brachyptera and $O$. tarda, WHITEHEAD (1996) discussed the taxonomic status of both names without studying type material and without arriving at plausible conclusions. It can be inferred from his diagnoses and illustrations that he attributed macropterous specimens to O. tarda and micropterous individuals to $O$. brachyptera. The rough sketches of the genitalia provided in the article suggest that most specimens he had identified as $O$. tarda in fact refer to O. brachyptera.

The drawings of the primary sexual characters in LOHSE (1974) indicate that the aedeagus of $O$. tarda is larger than that of $O$. brachyptera, but additional distinguishing characters are difficult to appreciate. Recently, KLIMASzEwsKi et al. (2006) published photographs of the habitus, as well as the primary and secondary sexual characters of $O$. brachyptera.

The ecology of O. brachyptera and O. tarda has been the subject of controversy. According to LoHse (1974), both species are found in the same localities, with O. tarda being the rarer of the two. Based on pitfall trap studies in northern Germany, Assing (1988) suggested that $O$. brachyptera is found in drier and warmer habitats on sandy soils, whereas O. tarda occurs in moist habitats on heavier soils. The observations pointed out by WHITEHEAD (1996) are not conclusive. The life histories of both species have never been studied in detail.

The present study was mainly initiated by repeated requests from colleagues regarding the identities, separation, and ecological characteristics of $O$. brachyptera and $O$. tarda. In order to verify if both species had been interpreted correctly, an examination of the type respective material was required. Also, since abundant material of both species had been accumulated in the course of numerous field studies during a period of more than two decades, a taxonomic study $O$. brachyptera and $O$. tarda provided an opportunity to clarify their natural history. 


\title{
Material and methods
}

The material treated in this study is deposited in the following public institutions and private collections:

$\mathrm{BMNH}$

SDEI

cAss

cSch

\author{
The Natural History Museum, London (R. G. Booth) \\ Senckenberg Deutsches Entomologisches Institut, Müncheberg (L. Zerche) \\ author's private collection \\ private collection Michael Schülke, Berlin
}

\section{Morphology and anatomy:}

The morphological studies were conducted using a Stemi SV 11 microscope (Zeiss Germany) and a Jenalab compound microscope (Carl Zeiss Jena). For the photographs a digital camera (Nikon Coolpix 995) was used.

Elytral length was measured at the suture from the apex of the scutellum to the posterior margin of the elytra. The length of the median lobe of the aedeagus was measured from the apex of the ventral process to the base of the capsule.

The parameral side of the median lobe of the aedeagus (i.e., the side where the sperm duct enters) is referred to as the ventral, the opposite side as the dorsal aspect.

The abdomen of several thousand females was dissected to examine the condition of the ovaries. The presence of mature eggs was interpreted as evidence of oviposition activity. In all the studied specimens the length of the hind wings was recorded. In order to assess the presence or absence of flight muscles, the thorax of more than a hundred macropterous specimens was dissected by removing the dorsal portion of the thoracal ectoscleleton.

\section{Ecology:}

During a period of more than two decades (1981-2001), field studies were conducted on the staphylinid fauna of a variety of habitats, particularly Calluna heathlands on sandy soils, in Niedersachsen, northern Germany. These studies yielded more than 100,000 adult Staphylinidae and more than 15,000 larvae. The localities where either Oxypoda brachyptera or O. tarda were recorded are listed in Tab. 1. For more details on these sites see Assing (1988, 1992, 1993, 1994), Hofmeister et al. (2001) and Melber et al. (1996).

In all the study sites pitfall traps were used to assess the species inventory and seasonal activity. The number of pitfall traps varied between three and 52 per year and site. For details regarding the type, construction, and maintenance of the pitfall traps see Melber (1987). The traps remained installed throughout the year (i.e., also in winter) and were emptied at half-monthly intervals, in some sites at monthly intervals. The data shown in Figs 26-27 are exclusively based on those full-year studies with pitfall traps that were emptied at half-monthly intervals. In all, more than 700 one-year pitfall traps were installed and maintained.

In addition to pitfall trapping, soil extractions after KEMPSON et al. (1963) were conducted in several heathlands to assess the densities of Staphylinidae. The samples were taken at halfmonthly intervals throughout the year. For more information on the field methods used see Assing (1993). 
Tab. 1: Study plots where either Oxypoda brachyptera or O. tarda were recorded. All sites are located in Niedersachsen, northern Germany.

\begin{tabular}{|c|c|c|c|}
\hline site & habitat & study period & methods \\
\hline $\begin{array}{l}\text { Helstorfer Reiterheide near Neustadt/ } \\
\text { Rbg. }\end{array}$ & $\begin{array}{l}\text { Calluna heathland in succession } \\
\text { to pine forest }\end{array}$ & 1981-91 & \begin{tabular}{|l|} 
pitfall traps, \\
soil extractions
\end{tabular} \\
\hline Lüneburger Heide, Niederhaverbeck & dry Calluna heathland & $1983-86$ & \begin{tabular}{|l|} 
pitfall traps, \\
soil extractions
\end{tabular} \\
\hline Lüneburger Heide, Niederhaverbeck & sandy grassland & 1986 & $\begin{array}{l}\text { pitfall traps, } \\
\text { soil extractions }\end{array}$ \\
\hline Lüneburger Heide, Schneverdingen & $\begin{array}{l}\text { Calluna heathland, grassy dunes } \\
\text { with sparse vegetation cover }\end{array}$ & 1992-2001 & pitfall traps \\
\hline Lüneburger Heide, Haverbeck & Calluna heathland & 1993-99 & pitfall traps \\
\hline Glider airfield Scheuen near Celle & Calluna heathland & 1984 & $\begin{array}{l}\text { pitfall traps, } \\
\text { soil extractions }\end{array}$ \\
\hline NSG „Heiliger Hain“ near Gifhorn & dry Calluna heathland & 1983-87 & $\begin{array}{l}\text { pitfall traps, } \\
\text { soil extractions }\end{array}$ \\
\hline NSG „Heiliger Hain“ near Gifhorn & sandy grassland & 1986 & \begin{tabular}{|l|} 
pitfall traps, \\
soil extractions
\end{tabular} \\
\hline NSG „Heiliger Hain“ near Gifhorn & sandy pine forest & 1987 & pitfall traps \\
\hline Bokeler Heide SE Bokel & grassy Calluna heathland & 1985-86 & pitfall traps \\
\hline Garlstedter Heide N Bremen & $\begin{array}{l}\text { sandy heathland with old } \\
\text { Calluna }\end{array}$ & 1985 & pitfall traps \\
\hline $\begin{array}{l}\text { NSG „Rössenbergheide-Külsenmoor“ } \\
\text { S Oerrel }\end{array}$ & $\begin{array}{l}\text { transsect from Calluna heat- } \\
\text { land to moist Erica heathland }\end{array}$ & $1986-1987$ & pitfall traps \\
\hline Wurster Heide near Cuxhaven & $\begin{array}{l}\text { Calluna heathland with } \\
\text { Empetrum }\end{array}$ & 1987 & pitfall traps \\
\hline Hannover & floodplain meadows & $1986 / 87$ & pitfall traps \\
\hline Hannover & moist fallows/meadows & $1986 / 87$ & pitfall traps \\
\hline Hannover & sandy grassland & $1986 / 87$ & pitfall traps \\
\hline Hannover & urban lawns & 1986-87, 1989 & pitfall traps \\
\hline Hannover & \begin{tabular}{|l|} 
cultivated gardens \\
\end{tabular} & $1986 / 87$ & pitfall traps \\
\hline Hannover & garden hedges/bushes & 1986-87, 1989 & pitfall traps \\
\hline Bad Nenndorf & garden & $1987 / 88$ & pitfall traps \\
\hline Öselberg near Wolfenbüttel & calcareous grassland & 1999 & pitfall traps \\
\hline Wernershöhe near Hildesheim & calcareous field margin & 1998 & pitfall traps \\
\hline Ortsberg near Alfeld/Leine & $\begin{array}{l}\text { xerothermous calcareous gras- } \\
\text { land with shrubs }\end{array}$ & $1985-87$ & pitfall traps \\
\hline Steinberg near Hildesheim & $\begin{array}{l}\text { xerothermous slopes (grassland, } \\
\text { shrubs, forests) }\end{array}$ & $1996 / 97$ & pitfall traps \\
\hline Düt near Hameln & $\begin{array}{l}\text { xerothermous sandy Arrhena- } \\
\text { theretum }\end{array}$ & 1990 & pitfall traps \\
\hline Immensen near Lehrte & sandy arable land & 1989 & pitfall traps \\
\hline
\end{tabular}




\section{Results}

In the course of the studies, nearly 8,000 adult specimens of $O$. brachyptera and approximately 450 specimens of $O$. tarda were examined (Tab. 2 and additional material examined). The bulk of this material was collected with pitfall traps. In order to ensure that the previous (and present) interpretation of both species is correct, the type material was studied.

Tab. 2: Number of adult specimens recorded in the study sites. The number of macropterous individuals is given in parentheses.

\begin{tabular}{|c|c|c|c|}
\hline site & habitat & brachyptera & tarda \\
\hline Helstorfer Reiterheide & Calluna heathland & $158(1)$ & \\
\hline Lüneburger Heide, Niederhaverbeck & dry Calluna heathland & 714 & \\
\hline Lüneburger Heide, Niederhaverbeck & sandy grassland & 33 & \\
\hline Lüneburger Heide, Schneverdingen & $\begin{array}{l}\text { dry, sparsely vegetated, grassy } \\
\text { Calluna heathland }\end{array}$ & $2892(105)$ & \\
\hline Lüneburger Heide, Haverbeck & Calluna heathland & $154(7)$ & \\
\hline Scheuen & Calluna heathland & 21 & \\
\hline Heiliger Hain & dry Calluna heathland & $2433(2)$ & \\
\hline Heiliger Hain & sandy grassland & 33 & \\
\hline Heiliger Hain & sandy pine forest & 5 & \\
\hline Bokeler Heide & grassy Calluna heathland & 1 & \\
\hline Garlstedter Heide & heathland with old Calluna & 14 & \\
\hline Rössenbergheide & Callunal Erica heathland & 281 & \\
\hline Wurster Heide & Calluna heathland & 1 & \\
\hline Hannover & floodplain meadows & & $417(4)$ \\
\hline Hannover & moist fallows/grassland & & 22 \\
\hline Hannover & sandy grassland & $136(20)$ & \\
\hline Hannover & urban lawns & $258(35)$ & \\
\hline Hannover & cultivated gardens & 13 & \\
\hline Hannover & garden hedges/bushes & 13 & \\
\hline Bad Nenndorf & garden & 1 & \\
\hline Öselberg & calcareous grassland & 7 & \\
\hline Wernershöhe & calcareous field margin & $124(1)$ & \\
\hline Ortsberg & $\begin{array}{l}\text { xerothermous calcareous grass- } \\
\text { land with shrubs }\end{array}$ & 21 & \\
\hline Steinberg & xerothermous slopes & $195(15)$ & \\
\hline Düt & xerothermous slopes & 6 & \\
\hline Immensen & sandy arable land & $2(1)$ & \\
\hline total & & $7826(187)$ & $439(4)$ \\
\hline
\end{tabular}


Oxypoda brachyptera (STEPHENS, 1832) (Figs 1-7, 15-18, 24-27)

Aleochara brachyptera STEPHENS, 1832: 128.

Oxypoda forticornis Fairmaire \& Brisout de Barneville, 1859: $37 \mathrm{f}$.

Bessopora subrugosa SAHLBERG, 1876: $111 \mathrm{f}$.

Oxypoda difficilis RouBAL, 1931: $70 \mathrm{f}$.

Oxypoda maritima Donisthorpe, 1932a: 3.

Oxypoda salictaria Donisthorpe, 1932b: 4.

Oxypoda brachyptera f. obscura KoRge, 1959: 61.

Oxypoda brachyptera f. wagneri Konge, 1959: $59 \mathrm{ff}$.

Type material examined:

Syntype $+:$ :h3 5/1 / 9 [6?] / Kirby / brachyptera / Syntype / Syntype Aleochara brachyptera Stephens from Kirby colln., det. R. G. Booth 2011 / Oxypoda brachyptera (Stephens) det. V. Assing 2011” (BMNH).

\section{Comment:}

The original description of Aleochara brachyptera is based on an unspecified number of syntypes from "Norfolk" and "Barham" (STEPHENS 1832). From the punctuation code (HAMmond 1972) used by STEPHENs (1829) and the fact that the species was attributed to "Kirby MSS" by Stephens $(1829,1832)$, it can be inferred that the syntypes are not deposited in the Stephens collection, but in other collections. One female syntype was located in the Kirby collection. This syntype is conspecific with the previous interpretation of Oxypoda brachyptera.

\section{Additional material examined:}

Apart from the material listed in Tab. 2, the following material was studied:

Germany: Niedersachsen: $1 \sigma^{\rightarrow}$ [macropterous], Hannover, Osterfelddamm, pitfall, VIII-IX.1991, leg. Sprick (cAss); $10^{\star}, 2$ 우 우 [micropterous], Hannover-Herrenhausen, garden, pitfall, IV.1986 (cAss); $1 \sigma^{*}$ [micropterous], same data, but VI.1985 (cAss); $20^{\star} 0^{*}$, Hannover-Langenhagen, sandy grassland, pitfall, V.1991, leg. Sprick (cAss); $4 o^{\star} o^{*}, 2$ \% 9 [micropterous], S Hannover Ronnenberg, potash mine, salt habitat, pitfall, VII.1995, leg. Schmidt (cAss); 1 ot [macropterous], Neustadt/Rbg., Himmelreich, window trap, VII.1991, leg. Assing (cAss); $1 \sigma^{\top}$ [micropterous], Hameln env., Großenwieden, field margin, pitfall, IV.1986, leg. Sprick (cAss); $2 \sigma^{\star} \sigma^{\star}$ [micropterous], Süntel, Rannenberg, calcareous arable land, pitfall, V.1988, leg. Sprick (cAss); 1 क [micropterous], Göttingen env., Fredelsloh, calcareous grassland, pitfall, VI.1984, leg. Joger (cAss); 1 क [micropterous], Bückeburg env., Ahnsen, arable land, pitfall, V.1986, leg. Sprick (cAss); 1 o $^{*}$ [micropterous], 1 ㅇ [macropterous], same data, VI.1986 (cAss); 1 ㅇ [micropterous], Braunschweig, arable land, V.1988 (cAss); 1 ㅇ [macropterous], Wilhelmshaven, Neuenburger Urwald, window trap, VIII.1996, leg. Menke (cAss). Schleswig-Holstein: 124 exs. [11 macropterous], Husum env., Beltringharder Koog

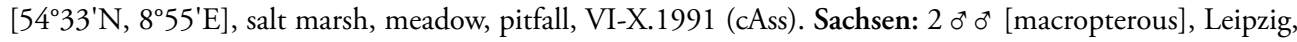
uncultivated arable land, pitfall, V.1995, leg. Sprick (cAss); $1 \sigma^{*}$ [macropterous], same data, but V-VII.1995 (cAss); 1 o $^{\star}$, Leipziger Auwald NSG Burgaue, window trap, 1.VII.2003 (cSch).

Austria: Kärnten: 1 ㅇ [micropterous], Gurktaler Alpen, Innerkrems, Gaipahöhe, 2100-2150 m, N-slope, 17.VII.1986, leg. Assing (cAss).

\section{Redescription:}

Small species; body length 2.2-2.6 mm. Coloration variable; usual coloration: head reddishbrown to blackish-brown; pronotum and elytra reddish-yellow to reddish; abdomen reddish, with segment VI and anterior portion of segment VII infuscate; legs yellowish to reddish-yellow; antennae dark-yellowish to brown. Occasionally, especially in macropterous specimens, the coloration is significantly darker, with the head almost blackish, the pronotum and elytra dark-brown, and the abdomen more extensively infuscate. 
Head transverse; eyes moderately large, approximately as long as postocular portion in lateral view, not larger in macropterous than in micropterous specimens. Antenna relatively long and massive, moderately and gradually incrassate apically; preapical antennomeres approximately 1.5 times as wide as long; antennomere XI with weakly pronounced sexual dimorphism, on average slightly longer in males than in females. Maxillary palpus not conspicuously elongated; preapical palpomere approximately 3 times as long as wide.

Pronotum approximately 1.35 times as broad as long, widest approximately in the middle; hind margin broadly convex, not distinctly bisinuate; punctation dense and shallow; interstices with microsculpture (Fig. 1).

Elytra dimorphic, in micropterous morph 0.7-0.8 times, in macropterous morph 0.90-0.95 times as long as pronotum; posterior margin distinctly sinuate near postero-lateral angles; punctation dense, usually somewhat coarser than that of pronotum (Fig. 2). Hind wings dimorphic, either fully developed (macropterous morph) or reduced to short stubs (micropterous morph); exceptionally (only one specimen seen) submacropterous. Metatarsomere I almost as long as combined length of metatarsomeres II-IV.

Abdomen with segments III-VI of subequal width; segments VII-X tapering. Punctation fine, dense on tergites III-VI, somewhat sparser on posterior tergites (Fig. 3); posterior margin of tergite VII with palisade fringe in both morphs; posterior margin of tergite VIII weakly convex.

$\sigma^{*}$ : sternite VIII produced posteriorly (Fig. 4); aedeagus with median lobe $0.30-0.35 \mathrm{~mm}$ long (Fig. 15-17); ventral process apically incised in ventral view (Fig. 18); paramere with long apical lobe.

ㅇ: sternite VIII with broadly convex posterior margin, with row of modified, stouter marginal setae (Fig. 5); spermatheca as in Figs 6-7.

\section{Systematic position:}

Oxypoda brachyptera is currently placed in the subgenus Bessopora THomson, 1859 (type species: Oxyopda testacea ERICHsOn, 1837).

\section{Comparative notes:}

In Central Europe, the only species of similarly small size, similar coloration, body shape, punctation, a pronounced pterodimorphism, and similar sexual characters is $O$. tarda. For notes on the separation of $O$. brachyptera from this species see the following section. In external morphology, the macropterous morph of $O$. brachyptera also somewhat resembles $O$. ferruginea ERICHSON, 1839, with which it has had a history of confusion (HORION 1967). For illustrations of the sexual characters of this species see Assing (2011). From similar Mediterranean representatives of the $O$. brachyptera group and of other species groups, such as O. caespita Assing, 2003, O. lesbia Assing, 2005, O. ahirica Assing, 2006, O. afimbriata Assing, 2006, O. praecisa Assing, 2006, and O. cingulum Bernhauer, 1902, O. brachyptera is separated by the combination of larger eyes, relatively longer elytra (even in the micropterous morph), the presence of a pterodimorphism, as well as by the sexual characters. For illustrations of the compared species see Assing (2003, 2005, 2006a, 2006b). For more images of the habitus, as well as of the primary and secondary sexual characters of $O$. brachyptera see KLIMASZEwsKI et al. (2006).

\section{Distribution:}

According to Horion (1967) and Smetana (2004), O. brachyptera is distributed in the North Palaearctic from Italy, France, and the British Isles across Central Europe eastwards to East Siberia and the Russian Far East. However, in view of frequent previous confusion with other similar 

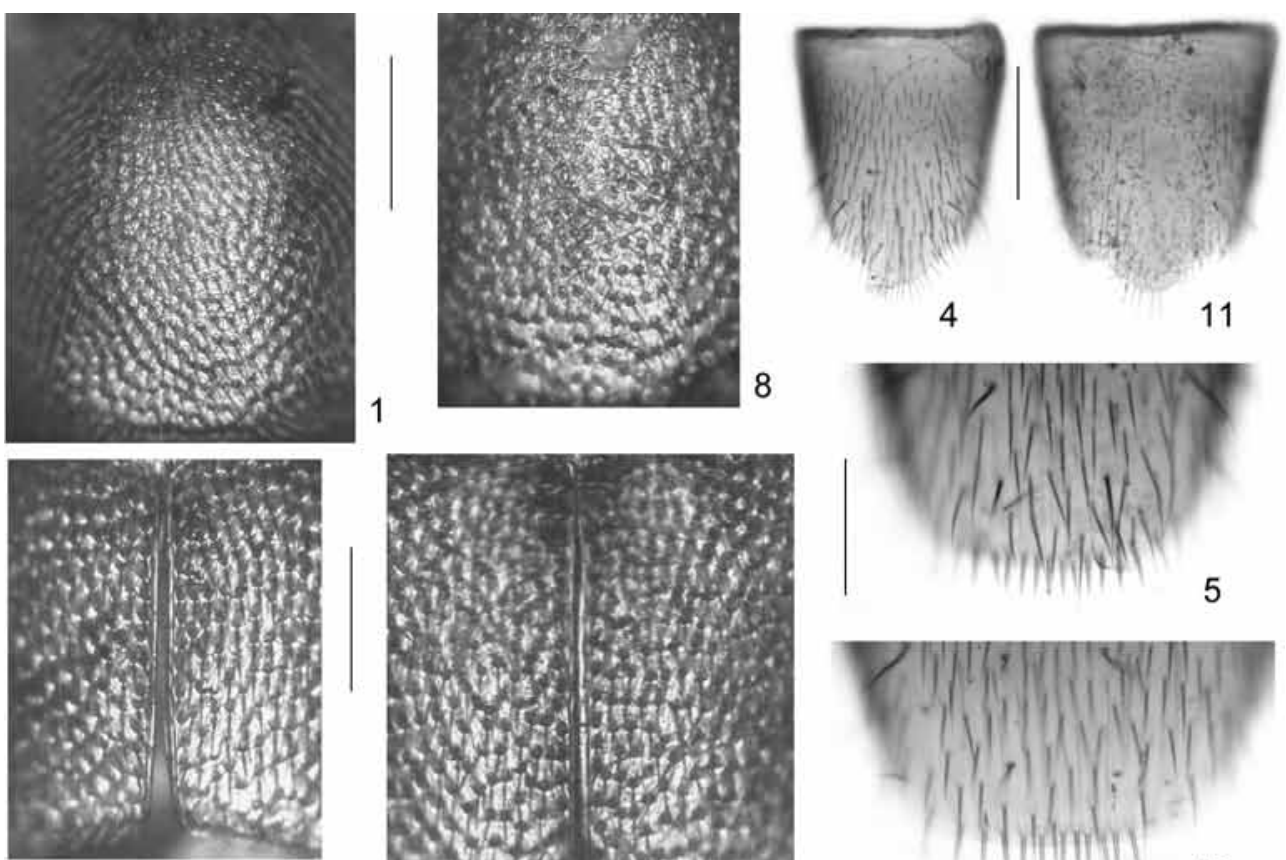

\section{2}
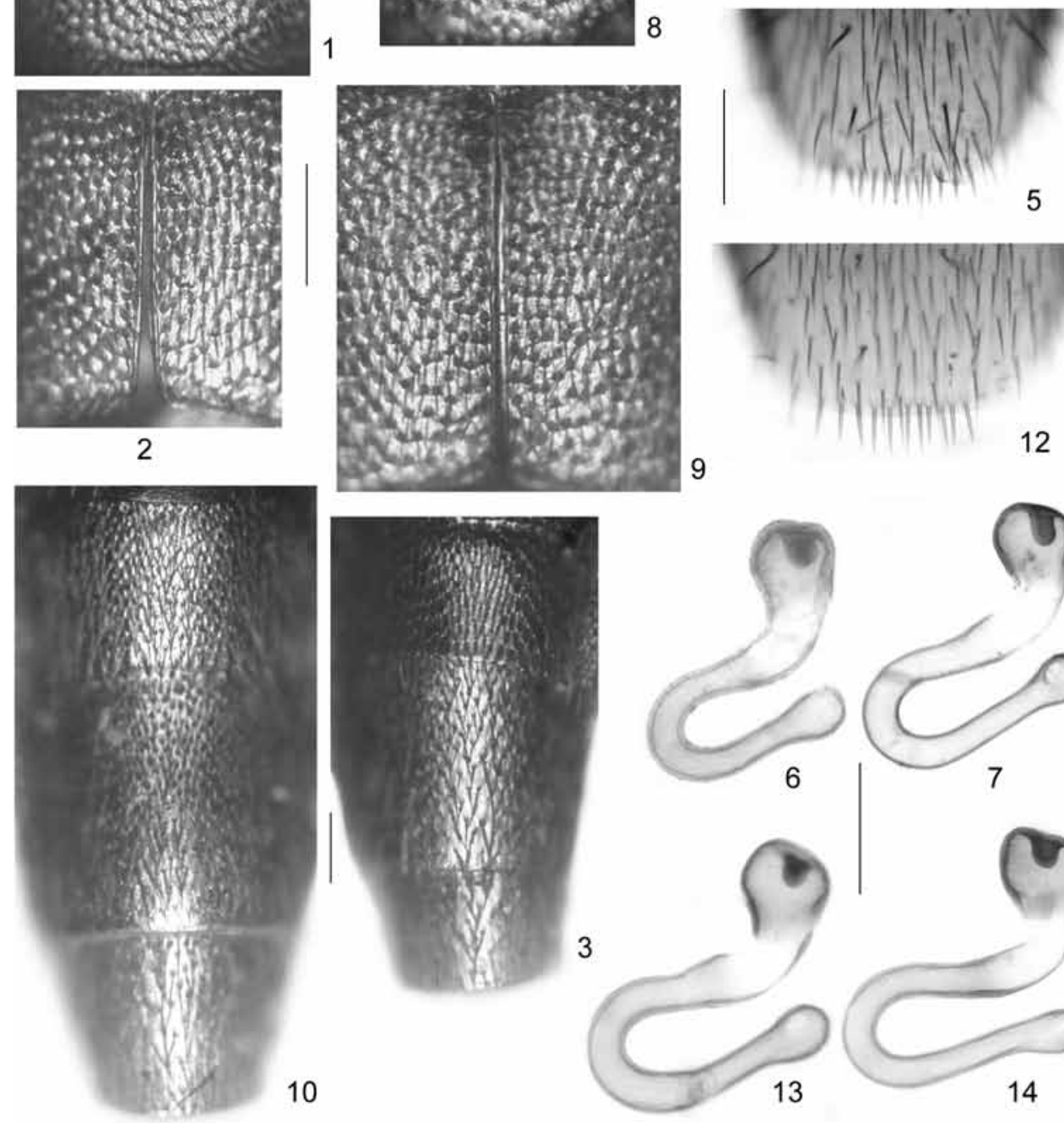

5
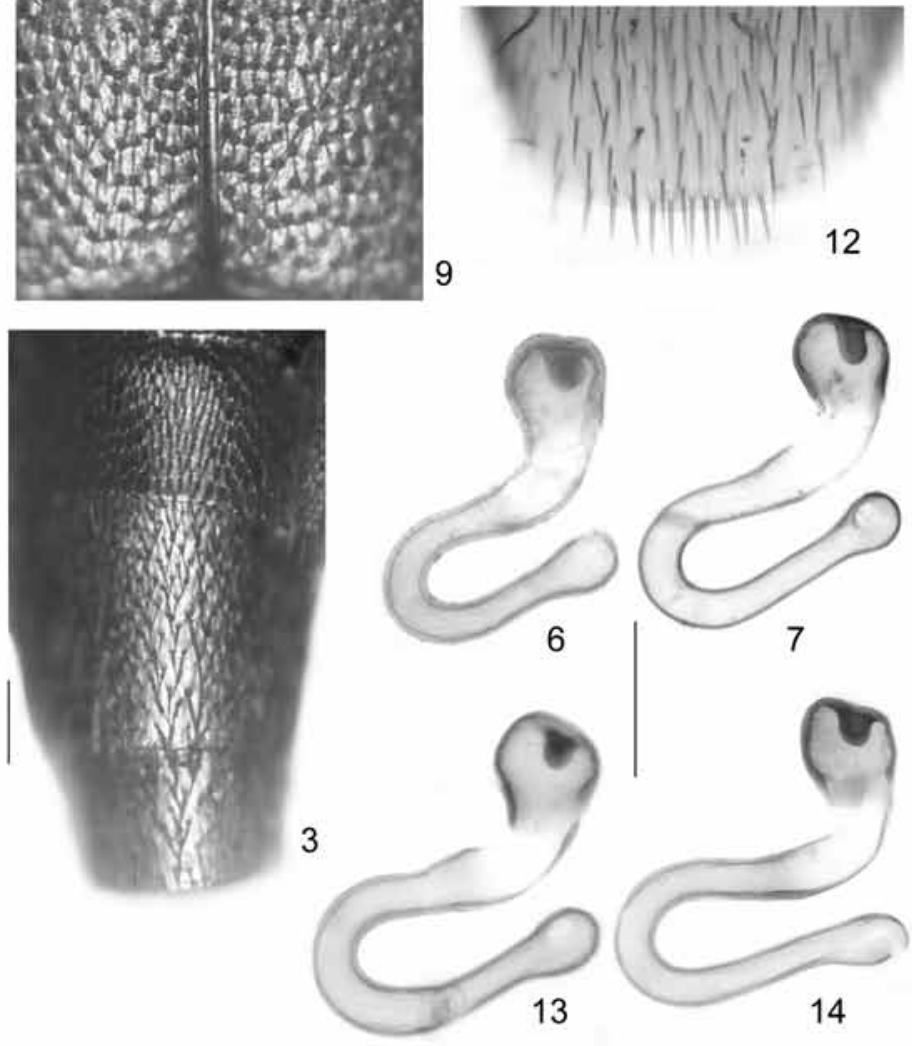

\section{9}

12

Figs 1-14: Oxypoda brachyptera (1-7; 6: syntype) and O.tarda (8-14; 11: lectotype; 13: paralectotype): median portion of pronotum $(1,8)$; median portion of elytra $(2,9)$; abdominal tergites VI-VIII $(3,10)$; male sternite VIII $(4,11)$; posterior portion of female sternite VIII $(5,12)$; spermatheca $(6-7,13-14)$. Scale bars: 4, 11: $0.2 \mathrm{~mm}$; 1-3, 5-10, 12-14: $0.1 \mathrm{~mm}$. 
Beitr. Ent. 62 (2012) 1
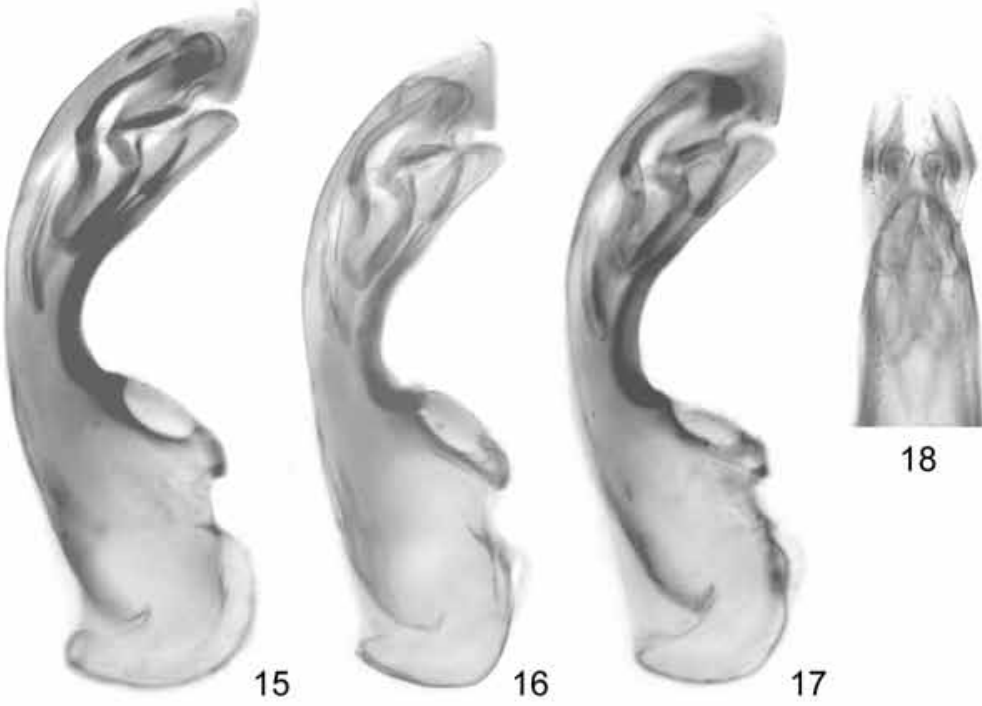

18

17

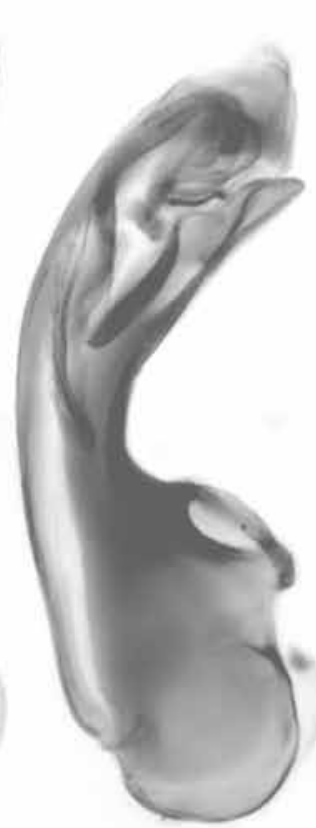

20

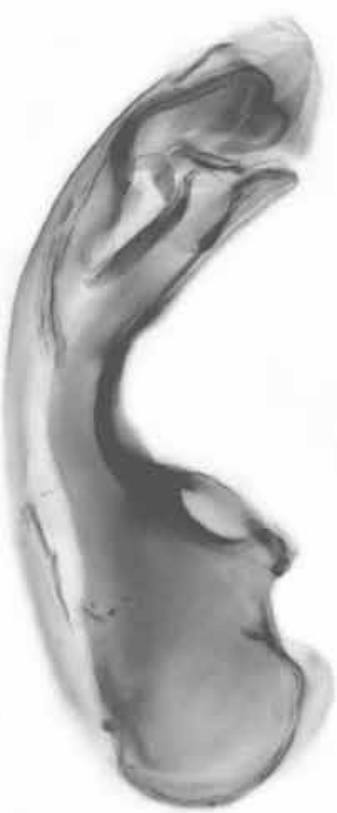

21

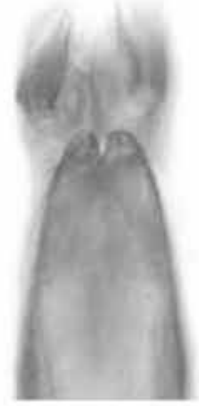

23

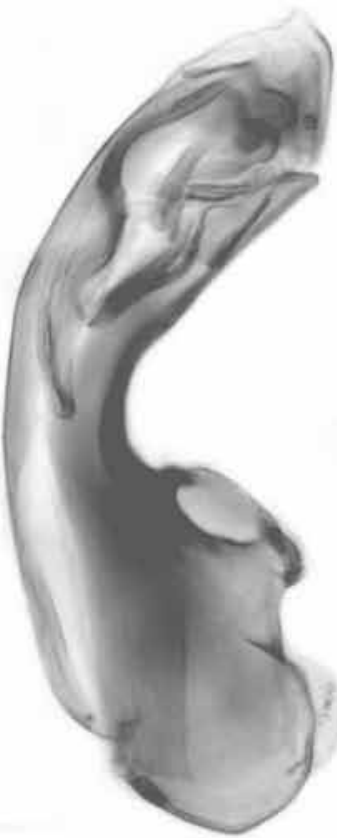

19

Figs 15-23: Oxypoda brachyptera (15-18) and O.tarda (19-23; 22: lectotype): median lobe of aedeagus in lateral view $(15-17,19-22)$; apical portion of median lobe in ventral view $(18,23)$. Scale bar: $0.1 \mathrm{~mm}$. 
Oxypoda species, the distribution requires revision. So far, I have seen true O. brachyptera only from Central Europe and Great Britain. KLimaszewski et al. (2006) report the species from Canada, where it is probably adventive.

\section{Natural history:}

Habitat. In northern Germany, O. brachyptera occurs in more or less unshaded lowland habitats on well-drained, sandy or calcareous soils (Tab. 2). It is particularly abundant in dry, xerothermous Calluna heathlands and in grasslands with either sparse or low vegetation cover (early succession stages of sandy habitats, lawns). The species was not recorded in dense forests, in moist grass- or heathland, and on heavy soils. In the pitfall transsect in the study site RössenbergheideKülsenmoor, it was recorded in greater numbers in the drier Calluna slopes, whereas it was absent from the lower Erica heathland (Fig. 24). One specimen was collected in a subalpine habitat in the Alp, at an altitude of 2100-2150 (see additional material examined). In view of the frequent confusion with other species, particularly $O$. tarda and $O$. ferruginea, possibly also the similarly coloured and similarly small O. exoleta ERICHSON, 1839, literature data on the ecology of O. brachyptera are mostly unreliable. HoRION (1967), for instance, reports the species from both moist soils, shores, and banks, and from dry sandy soils.

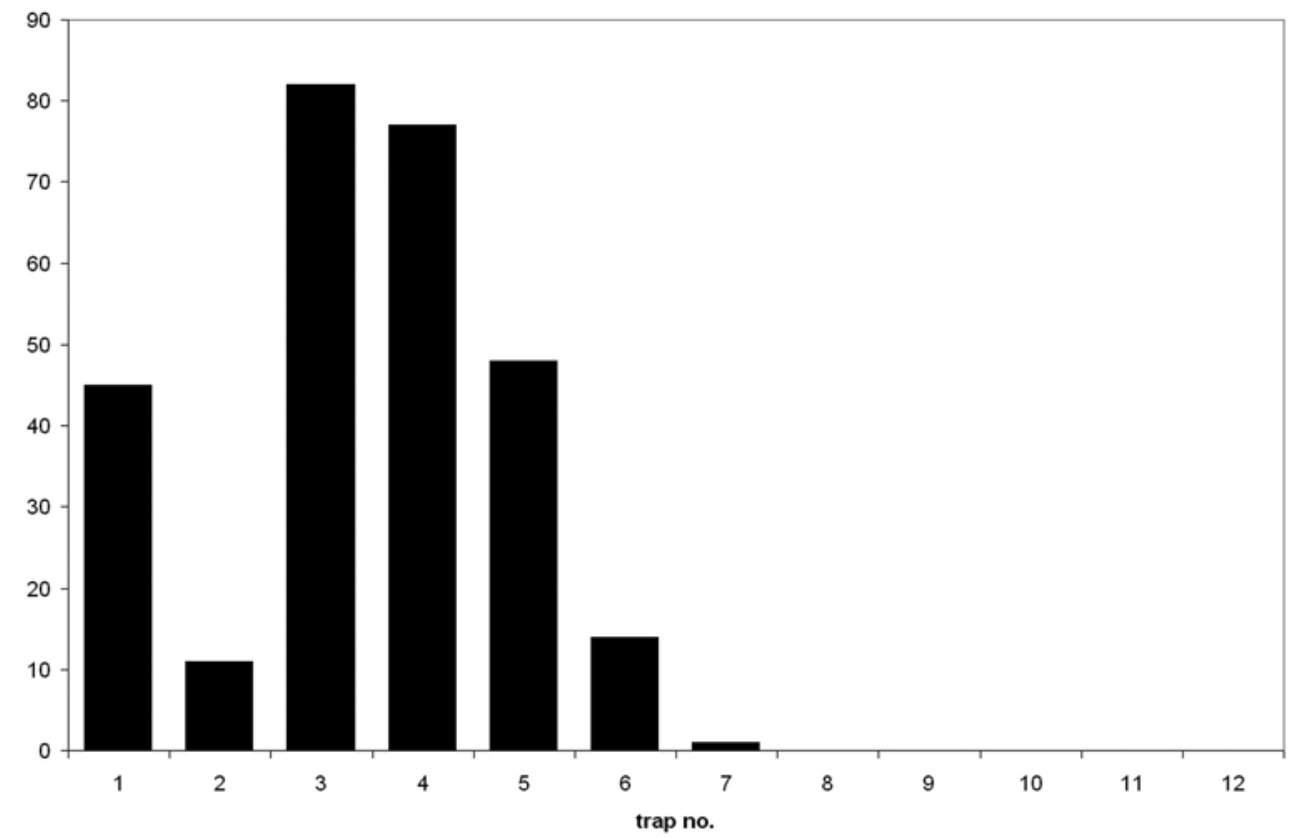

Fig. 24: Pitfall trap catches of O. brachyptera in a transsect in the study site Rössenbergheide-Külsenmoor. Traps 1-6 were situated on a dry Calluna slope, 8-12 in an adjacent Erica heathland, and 7 at the border between both habitats.

\section{Phenology:}

Adult $O$. brachyptera were recorded with pitfall traps from the beginning of March to the beginning of December. However, epigeic activity is low to very low in March and from September through the first half of December and probably only occurs when the weather conditions are favourable. The core activity period lasts from April through August, with a conspicuous peak in the second half of April and two less evident maxima in the second half of June and in the second half of August (Fig. 25). 
In some study sites, especially Heiliger Hain and Schneverdingen, O. brachyptera was among the most abundant staphylinid species in the pitfall traps, despite its small body size. As can be seen in Fig. 26, the pooled seasonal densities are relatively low. They are highest in spring and range between less than one to approximately 4.5 individuals per square meter. Thus, it can be concluded that, in comparison to other staphylinids of similar and even larger body size, the epigeic activity of $O$. brachyptera from April through August is enormous. The sex ratio (males:females) in the soil samples was 0.62 , whereas in the pitfall traps it was 1.24 , suggesting that the epigeic activity of males is distinctly greater than that of females. This particularly applies to the period from the second half of April through the first half of August, during which time the proportions of males in the pitfall traps ranged between 55.5 and $61.6 \%$.

As can be inferred from the data shown in Fig. 27, O. brachyptera apparently has two generations per year. Oviposition takes place from the second half of March to the second half of September. However, there are two maxima, one from mid-April to mid-May and one from Mid-June to mid-August. Emergence from the pupa occurs from the beginning of May to the first half of December, again with two maxima. The first one is from the beginning of June to mid-July and the second one in the second half of August. A comparison of the two curves in Fig. 27 suggests that pre-imaginal development from oviposition to emergence from the pupa lasts approximately 1.5-2 months and that hibernation occurs in the adult stage. There appears to be no aestivation period or diapause.

On one occasion (Hannover, August), one dissected female was found to be infested with nematodes.

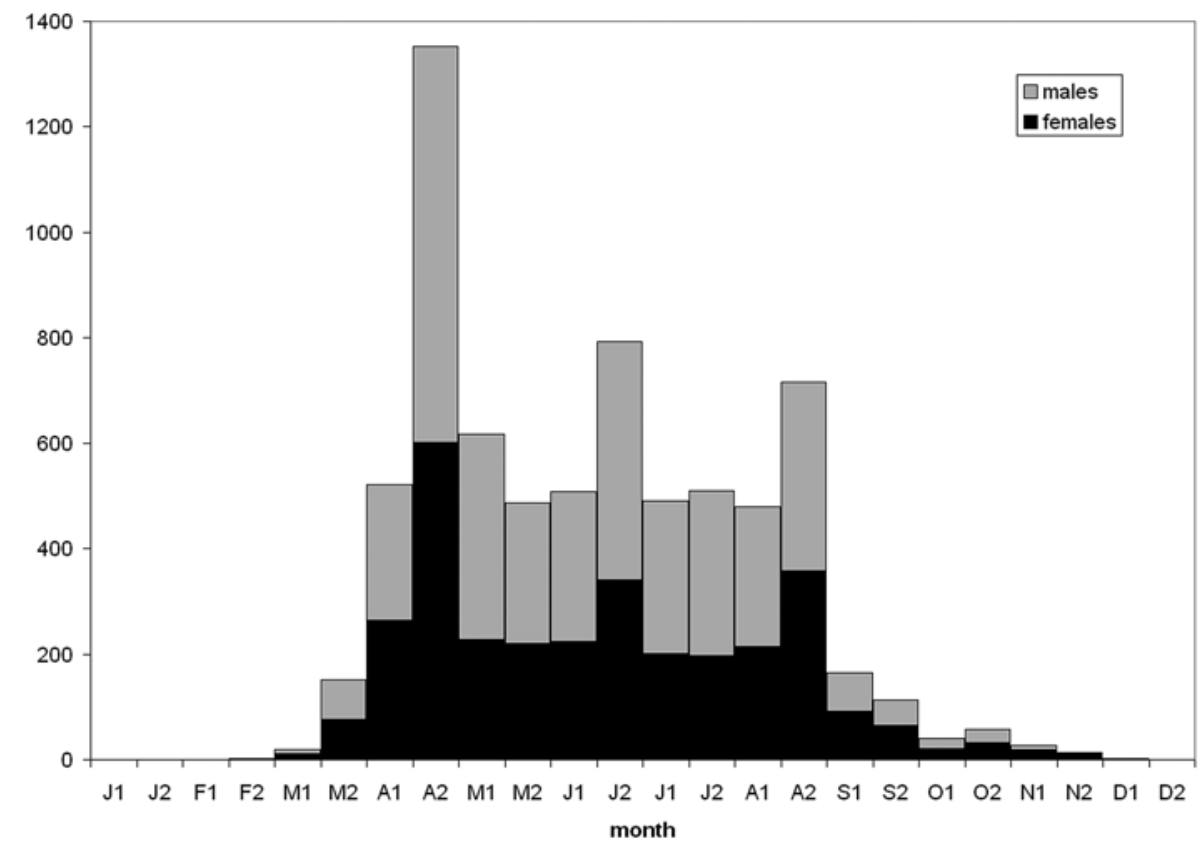

Fig. 25: Pooled seasonal activity density of $O$. brachyptera based on pitfall trap studies in 20 study plots in Niedersachsen during the period from 1981 to 2001 (total: 7110 specimens). The months are given in halfmonthly intervals $(\mathrm{F} 1 \mathrm{=}$ first half of February, F2 = second half of February, etc.). 


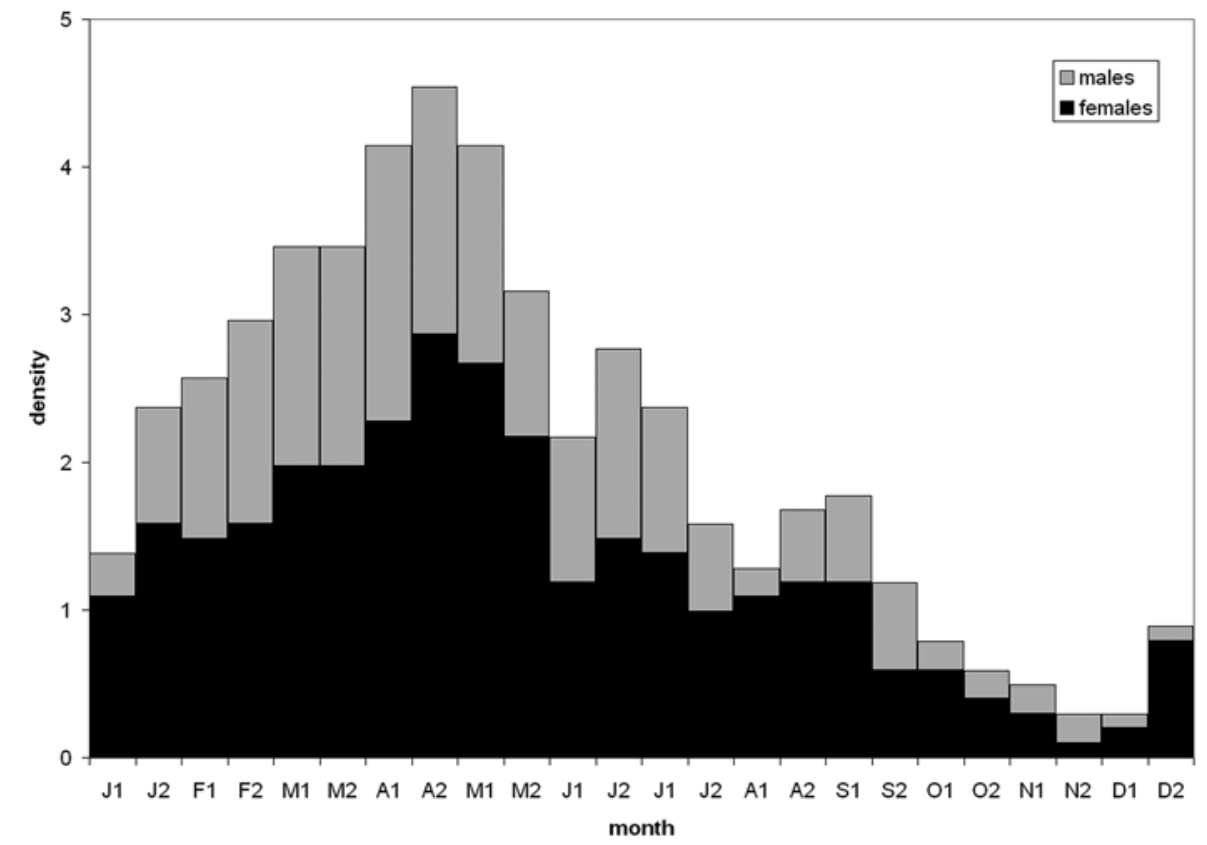

Fig. 26: Pooled seasonal densities (individuals $/ \mathrm{m}^{2}$; floating arithmetic means) of O. brachyptera based on full-year soil extractions in 6 heathland study plots in Niedersachsen during the period from 1981 to 1986 (total: 165 specimens). For additional explanations see Fig. 25.

\section{Pterodimorphism and dispersal:}

The wing dimorphism in $O$. brachyptera is not sex-related; the proportions of both morphs were similar for both sexes. In all the study plots, the vast majority of specimens was micropterous. The macropterous morph made up only some $2.4 \%$ of the grand total. The proportion of macropterous specimens was highest in sandy habitats in early succession stages, in urban habitats (lawns, sandy grassland) (Tab. 2), on arable land, and in a coastal meadow. Approximately $85 \%$ of the dissected macropterous specimens had fully developed flight muscles. It is uncertain if the absence of flight muscles in the remaining $15 \%$ is a result of post-mortem decay, genetic disposition, or metabolic reduction. In any case, the data suggest that at least the vast majority of macropterous individuals is capable of flight. On three occasions, flying specimens were recorded with window traps in July and August.

Oxypoda tarda SHARP, 1871 (Figs 8-14, 19-23, 28)

Oxypoda tarda SHARP, 1871: 192.

\section{Type material examined:}

Lectotype $\sigma^{\star}$, present designation: "1066 [written on reverse side of mounting label] / brachyptera Steph., ferruginea Er., forticornis Fairm. / tarda / Syntype / D. Sharp Coll. B. M. 1932-116 / Lectotypus o Oxypoda tarda Sharp, desig. V. Assing 2011 / Oxypoda tarda Sharp, det. V. Assing 2011" (BMNH). Paralectotypes: $1 \sigma^{\star}$ : "1066 [written on reverse side of mounting label] / tarda Sharp. / Syntype / D. Sharp Coll. B. M. 1932-116” (BMNH); 3 ․ :1066 [written on reverse 


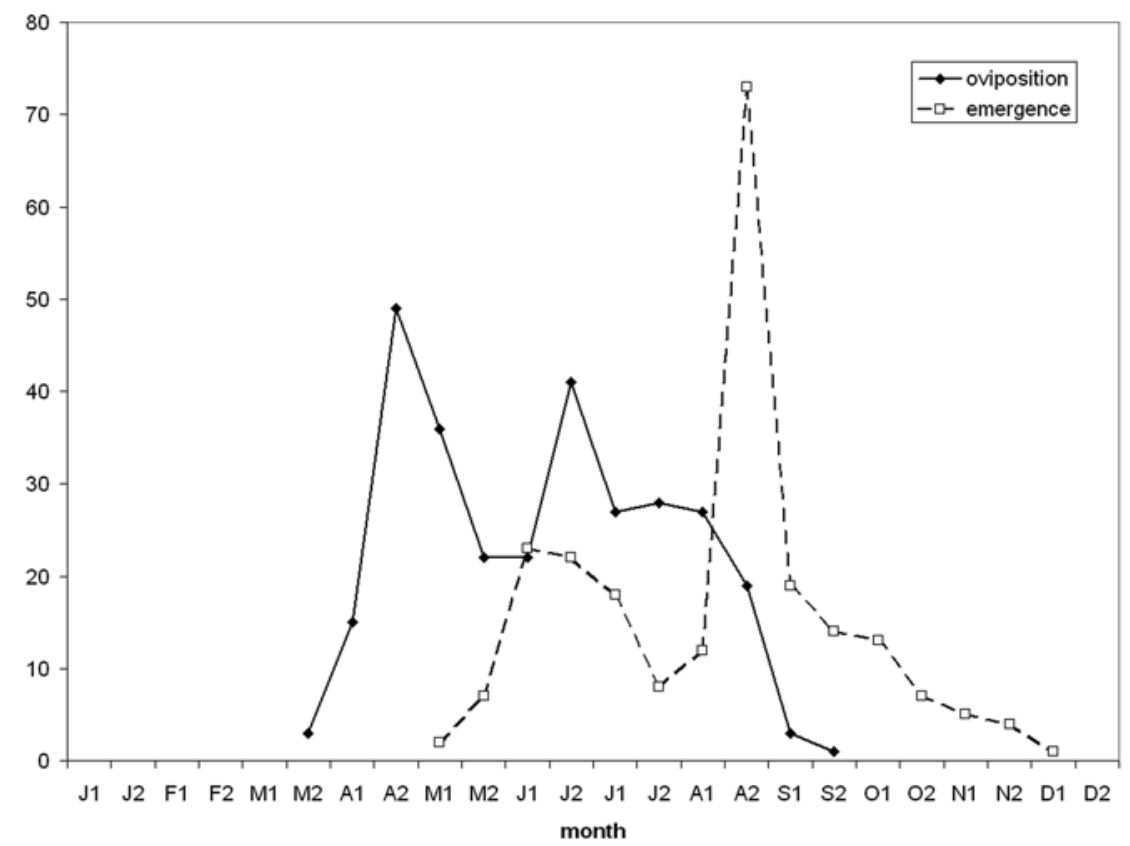

Fig. 27: Oviposition activity and emergence of adults from the pupa in O. brachyptera. Oviposition activity is given as the number of females with mature eggs in ovaries, emergence as the presence (not number) of teneral adults per trap series (study plot) and year.

side of mounting label] / Syntype / D. Sharp Coll. B. M. 1932-116” (BMNH); 1 \%: "1066 [written on reverse side of mounting label] / tarda / Syntype / D. Sharp Coll. B. M. 1932-116" (BMNH); 1 : : 1066 [written on reverse side of mounting label] / O. tarda Sharp / brachyptera Steph., forma major, obscura / Syntype / D. Sharp Coll. B. M. 1932-116” (BMNH); 1 ㅇ : "1066 [written on reverse side of mounting label] / O. tarda type. D. S. / Syntype / D. Sharp Coll. B. M. 1932-116" (BMNH).

\section{Comment:}

The original description is based on several syntypes ("all the specimens I have seen") from "the salt marshes near Dumfries" (Sharp 1871). Eight syntypes were located in the Sharp collection at the BMNH. One of the two males is designated as the lectotype. According to BоoтH (e-mail 3 Oct., 2011), Sharp's catalogue number 1066 refers to Caelaverock on the coast just south of Dumfries, 25 May 1867. According to the description, O. tarda is distinguished from O. brachyptera by larger body size, darker coloration, the uniformly dark coloration of the abdomen, relatively somewhat shorter and more slender antennae, and slightly longer elytra.

\section{Additional material examined:}

Apart from the material listed in Tab. 2, the following material was studied:

Germany: Niedersachsen: $1 \sigma^{\text {t }}$ [macropterous], Hannover, Osterfelddamm, pitfall, VIII-IX.1991, leg. Sprick (cAss); 1 ㅇ [micropterous], W Hannover, Haste, arable land, VI.1987 (cAss); $1 \sigma^{\star}$ [micropterous], Süntel, Rannenberg, calcareous arable land, pitfall, VI.1987, leg. Sprick (cAss); 1 đ [micropterous], same data, but V.1988 (cAss); 2 우 [micropterous], Bückeburg env., Ahnsen, shrubs, pitfall, VI.1986, leg. Sprick (cAss); 1 \% [micropterous], same data, but meadow, XII.1985 (cAss); 1 \% [macropterous], same 
data, but arable land, VII.1986 (cAss); $1 \sigma^{\star}, 2$ exs. [micropterous], Stadthagen, moist forest clearing, pitfall, VIII-IX.1991, leg. Sprick (cAss); 1 o [micropterous], Harz, St. Andreasberg, 700 m, pitfall, VIII-IX.1991

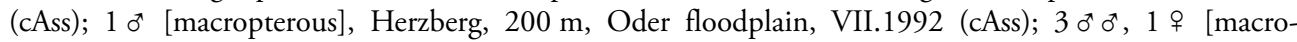
pterous], Braunschweig env., Hötzum, arable land, VI.1988 (cAss); $10^{\text {t }}$ [macropterous], Braunschweig, arable land, VI.1988 (cAss). Schleswig-Holstein: 1 \% [micropterous], Neustadt in Holstein env., Brodau,

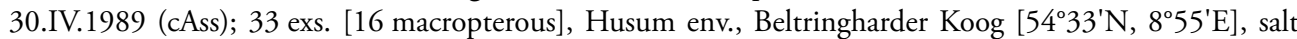
marsh, meadow, pitfall, V-X.1991 (cAss). Hessen: $20^{\top} o^{\star}$ [micropterous], Hanau env., Schlüchtern, pitfall, VII.1993, leg. Sprick (cAss). Nordrhein-Westfalen: $1 \sigma^{\star}$ [micropterous], Höxter env., Beverungen, pitfall, 17.V.1990 (cAss).

\section{Diagnosis:}

Body length $2.5-3.0 \mathrm{~mm}$. Coloration similar to that of $O$. brachyptera and similarly variable, but specimens of darker coloration are more common than in $O$. brachyptera. Body shape on average slightly broader than in $O$. brachyptera.

Elytra dimorphic, in micropterous morph 0.75-0.90 times, in macropterous morph 0.900.95 times as long as pronotum. Hind wings either fully developed (macropterous morph) or reduced to short stubs (micropterous morph), these rudiments slightly longer than elytra.

Abdomen punctation of tergite VII practically as dense as that of anterior tergites (Fig. 10); posterior margin of tergite VII with palisade fringe in both morphs.

Other external characters (punctation, microsculpture, etc.) as in O. brachyptera (Figs 8-9).

$\sigma^{\star}$ : sternite VIII of similar shape as that of $O$. brachyptera (Fig. 11); median lobe of aedeagus 0.38-0.40 mm long, of similar morphology (including internal structures) as that of $O$. brachyptera, but apex of ventral process more acute in lateral view and internal structures longer (Figs 19-23).

9 : sternite VIII of similar shape and chaetotaxy as that of $O$. brachyptera (Fig. 12); spermatheca of similar shape as that of O. brachyptera, but apical cuticular intrusion slightly less deep (Figs 13-14).

\section{Comparative notes:}

Oxypoda tarda is most reliably distinguished from the extremely similar O. brachyptera by the larger median lobe of the aedeagus (no overlap) and the more acute apex of the ventral process of the aedeagus in lateral view (see Figs 15-17 and Figs 19-22). Additional, but less reliable characters are the on average longer elytra (in both morphs), the on average darker coloration, the on average larger and broader body, and the more densely punctate abdominal tergite VII (see Figs 3, 10).

\section{Distribution:}

According to Smetana (2004), the distribution of O. tarda is confined to Denmark, Sweden, and Germany. Remarkably, Great Britain is not listed in the catalogue, although the species was described from Scotland. For additional records from Germany, Denmark, and Sweden see Baranowski (1979), Brenner (1993), Feldmann \& Lückmann (1998), Hansen et al. (1995), Hennicke \& Müller-Motzfeld (1998), Klausnitzer et al. (1980), Köhler (1997), Korge (1990), Kunze \& Kache (1998), Lundberg (1978a-b), Renner (2001), Rose (2000), Vogel (1978, 1980), and Vogel \& Dunger (1980); references with obviously doubtful records from habitats that are generally inhabited by $O$. brachyptera are not included. It appears likely that $O$. tarda is much more widespread, but owing to its similarity to, and the previous confusion with $O$. brachyptera, it is unknown which of the literature records of $O$. brachyptera in fact refer to $O$. tarda. 


\section{Natural history:}

Habitat. In northern Germany, O. tarda is not particularly rare. The examined material was found in various unforested, generally in more or less moist habitats on heavier, often more or less loamy, or on calcareous soils, particularly in moist meadows, floodplains, arable land, fallows, and in coastal meadows. The species appears to be absent from dry habitats on sandy soils.

According to LoHse (1974), O. tarda occurs in the same localities as O. brachyptera. However, the present data do not confirm this observation. In the vast majority of the studied sites, only either of the two species was present. Both species were recorded as syntopic only in a coastal meadow, in arable land, and in a fallow. In most cases of syntopic occurrence, at least one of the two species was represented exclusively by the macropterous morph. In localities where either of the two species was very abundant, the other species was always absent (Tab. 2). Thus, regarding their respective habitats, $O$. tarda and $O$. brachyptera appear to be clearly segregated.

\section{Phenology:}

The epigeic activity period measured with pitfall traps in 1986/1987 lasted from May to the first half of November. The highest activity was observed from the second half of May through June and in September (Fig. 28). The sex ratio (males:females) was similar to that of O. brachyptera (1.27). Mature eggs were found in the ovaries of dissected females from the second half of June through the first half of August. Teneral adults were observed from the second half of August through September, with a maximum in the second half of September. These data suggest that $O$. tarda has only one generation per year, that the duration of pre-imaginal development is similar to that of $O$. brachyptera (1.5-2 months, without diapause), and that hibernation occurs in the adult stage.

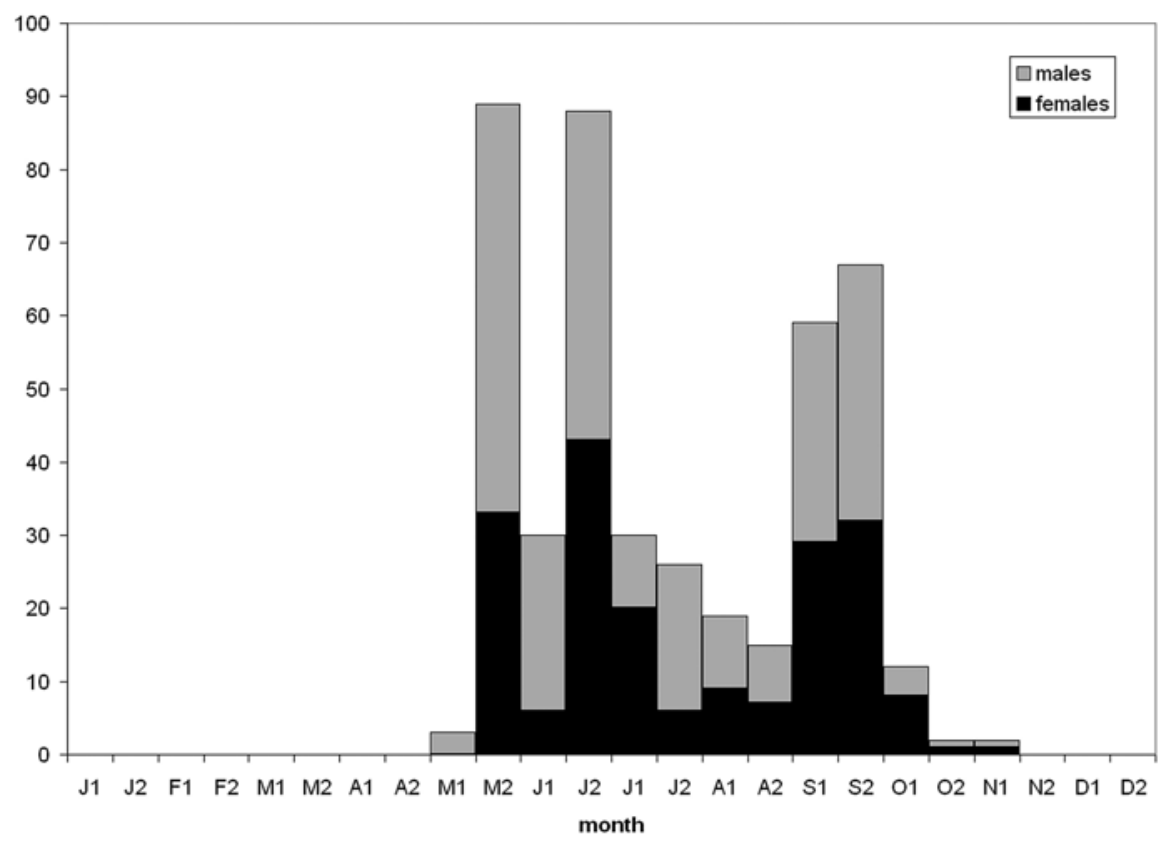

Fig. 28: Pooled seasonal activity density of O. tarda based on pitfall trap studies in Hannover in 1986/1987 (total: 442 specimens). For additional explanations see Fig. 25. 


\section{Pterodimorphism:}

As in O. brachyptera, the micropterous morph of O. tarda is much more common than the macropterous morph (Tab. 2). At least this is true of the study sites where the species was abundant. Higher proportions of the macropterous morph were observed only on arable land and in a salt meadow. The flight muscles were not studied, and flying specimens have not been recorded.

\section{Acknowledgements}

I am indebted to Roger Booth (BMNH) for the loan of the type material of O. brachyptera and O. tarda. Several colleagues were of invaluable help in organising and conducting the field studies, in particular Albert Melber (Hannover), Ludger Schmidt (Neustadt/Rbg.), and Peter Sprick (Hannover). Benedikt Feldmann (Münster) proof-read the manuscript.

\section{References}

AssınG, V. 1988: Die Kurzflügelkäferfauna (Coleoptera: Staphylinidae) ausgewählter Grün-, Ruderal- und Kleingartenflächen im Stadtgebiet Hannovers: Ein Beitrag zur Faunistik und Ökologie einer Großstadt. - Berichte der Naturhistorischen Gesellschaft Hannover 130: 111-131.

Assing, V. 1992: Die Kurzflügelkäfer (Coleoptera: Staphylinidae) eines urbanen Inselbiotopkomplexes in Hannover. 3. Beitrag zur Faunistik und Ökologie der Staphyliniden von Hannover. - Berichte der Naturhistorischen Gesellschaft Hannover 134: 173-187.

Assing, V. 1993: Zur Bionomie von Xantholinus rhenanus Coiff. und anderen bodenbewohnenden Xantholininen (Coleoptera, Staphylinidae) in Nordwestdeutschland. - Zoologische Jahrbücher. Abteilung für Systematik, Ökologie und Geographie der Tiere, Jena 120: 13-38.

Assing, V. 1994: Zur Kurzflügelkäferfauna xerothermer Flächen im südlichen Niedersachsen (Coleoptera: Staphylinidae). - Göttinger naturkundliche Schriften 3: 7-31.

Assing, V. 2003: New species and records of Oxypoda Mannerheim from Spain (Coleoptera: Staphylinidae, Aleocharinae). - Linzer biologische Beiträge 35 (2): 813-829.

Assing, V. 2005: Two new species and new records of Staphylinidae from the Greek island Lesbos (Insecta: Coleoptera). - Linzer biologische Beiträge 37 (2): 1035-1046.

Assing, V. 2006a: On some species of Oxypoda Mannerheim from Turkey and adjacent regions (Insecta: Coleoptera: Staphylinidae, Aleocharinae). - Linzer biologische Beiträge 38 (1): 277-331.

Assing, V. 2006b: New species and records of Staphylinidae from Greece, with two new synonymies (Insecta: Coleoptera). - Linzer biologische Beiträge 38 (1): 333-379.

Assing, V. 2011: On the Staphylinidae of Turkey VIII. Eleven new species, two new synonymies, a new combination, and additional records (Coleoptera: Staphylinidae). - Koleopterologische Rundschau 81: 179-227.

BARANOWSKI, R. 1982: Intressanta skalbaggsfynd 4. - Entomologisk Tidskrift 100: 71-80.

Bernhauer, M. 1902: Die Staphyliniden der paläarktischen Fauna. I. Tribus: Aleocharini. (II. Theil.). Verhandlungen der Kaiserlich-Königlichen Zoologisch-Botanischen Gesellschaft in Wien 52 (Beiheft): 87-284.

Bernhauer, M. \& Scheerpeltz, O. 1926: Staphylinidae VI. - In: Junk, W. \& Schenkling, S. (eds.): Coleopterorum Catalogus, pars 82, Berlin: 499-988.

Brenner, U. 1993: Beitrag zur Kenntnis der Käferfauna auf den Halbtrockenrasen der Eifel (Insecta; Coleoptera). - Mitteilungen der Arbeitsgemeinschaft Rheinischer Koleopterologen (Bonn) 3 (4): 135-159.

Donisthorpe, H. 1932a: Oxypoda maritima n. sp., a species of Coleoptera (Staphylinidae) new to science. - The Entomologist's Monthly Magazine 68: 3-4. 
Donisthorpe, H. 1932b: Oxypoda salictaria n. sp., a species of Coleoptera (Staphylinidae) new to science, and a few remarks on other species. - The Entomologist's Monthly Magazine 68: 4-8.

Fairmaire, L. \& Brisout de Barneville, C. 1859: 21. Oxypoda forticornis. - In: Fairmaire, L.: Miscellanea entomologica. Troisième partie. - Annales de la Société Entomologique de France 7 (3): 21-64.

Feldmann, B. \& Lückmann, J. 1998: Zur Staphylindienfauna (Coleoptera) der Kalkmagerrasen im Raum Marsberg. - Mitteilungen der Arbeitsgemeinschaft Rheinischer Koleopterologen (Bonn) 8: 73-100.

Ganglbauer, L. 1895: Die Käfer von Mitteleuropa. 2. Band: Staphylinidae und Pselaphidae. - Wien: $850 \mathrm{pp}$.

Hammond, P. M. 1972: On the type material of Staphylinidae (Coleoptera) described by T. Marsham and J. F. Stephens. - Entomologist's Gazette 23: 129-135.

Hansen, M.; Liljehult, H.; Mahler, V. \& Pedersen, J. 1995: 14. till³g til „Fortegnelse over Danmarks biller" (Coleoptera). - Entomologisk Meddelelser 63: 21-50.

Hennicke, S. \& Müller-Motzfeld, G. 1998: Die Besiedlung innerstädtischer Grünflächen Greifswalds durch Kurzflügeldecken-Käfer (Coleoptera: Staphylinidae). - Entomologia Generalis 23 (1/2): 107-127.

Hofmeister, H.; Prüss, U.; Sprick, P. \& Weber, U. 2001: Der Steinberg bei Wesseln. Mitteilungen der Paul-Feindt-Stiftung. - Natur und Landschaft im Landkreis Hildesheim, Heft 2: 72-76.

Horion, A. 1967: Faunistik der mitteleuropäischen Käfer. Bd. XI: Staphylinidae, 3. Teil: Habrocerinae bis Aleocharinae (ohne Subtribus Athetae). - Überlingen-Bodensee: 419 pp.

Joy, N. H. 1932: A practical handbook of British beetles. Vol. I. - London: 622 pp.

Kempson, D.; Lloyd, M. \& Ghelardi, R. 1963: A new extractor for woodland litter. - Pedobiologia 3: $1-21$.

Klausnitzer, B.; Richter, K.; Köвerlein, C. \& Köвerlein, F. 1980: Faunistische Untersuchungen der Bodenarthropoden zweier Leipziger Stadtparks unter besonderer Berücksichtigung der Carabidae und Staphylinidae. - Wissenschaftliche Zeitschrift der Karl-Marx-Universität Leipzig, MathematischNaturwissenschaftliche Reihe 29 (6): 583-597.

Klimaszewski, J.; Pelletier, G.; Germain, C.; Work, T. \& Hébert, C. 2006: Review of Oxypoda species in Canada and Alaska (Coleoptera, Staphylinidae): systematics, bionomics, and distribution. - The Canadian Entomologist 138: 737-852.

KöHLER, F. 1997: Anmerkungen zur lokalfaunistischen Käfersammlung der landwirtschaftlichen Versuchsgüter Burscheid-Höfchen und Monheim-Laacherhof im Fuhlrott-Museum Wuppertal (Insecta, Coleoptera). - Jahresberichte des naturwissenschaftlichen Vereins Wuppertal 50: 59-80.

Korge, H. 1959: Oxypoda-Studien (Coleoptera, Staphylinidae). - Mitteilungen der Deutschen Entomologischen Gesellschaft 18 (4): 58-65.

Korge, H. 1990: Beiträge zur Kenntnis der Tierwelt von Berlin (West). Teil I: Kurzflügelkäfer (Coleoptera Staphylinidae). - In: Entomologische Gesellschaft ORION: 100 Jahre Entomologische Gesellschaft ORION - Berlin: 57-77.

Kunze, M. \& KaChe, P. 1998: Zonationszönosen von Kurzflügelkäfern (Coleoptera: Staphylinidae) an Flußufern Nordwestdeutschlands. - Zeitschrift für Ökologie und Naturschutz 7: 29-43.

Lohse, G. A. 1970: Oxypoda-Studien. - Entomologische Blätter 66 (2): 66-72.

Lohse, G. A. 1974: Tribus 15-19 (Schistogenini - Aleocharini). - In: Freude, H.; Harde, K. W. \& Lohse, G. A. (eds.): Die Käfer Mitteleuropas, Bd. 5, Krefeld: 221-292.

LoHSE, G. A. 1989: Ergänzungen und Berichtigungen zu Band 5. 23. Familie Staphylinidae (II) (Aleocharinae). - In: Lohse, G. A. \& Lucht, W. H. (eds.): Die Käfer Mitteleuropas. 1. Supplementband mit Katalogteil, Krefeld: 185-239.

LundberG, S. 1978a: Bidrag till kännedom om svenska skalbaggar. 17 (Coleoptera). - Entomologisk Tidskrift 99: 31-34.

Lundberg, S. 1978b: Fynd av för Sverige nya skalbaggsarter rapporterade under åren 1976-1977 (Coleoptera). - Entomologisk Tidskrift 99: 61-63. 
Melber, A. 1987: Eine verbesserte Bodenfalle (Kurzartikel). - Abhandlungen Naturwissenschaftlicher Verein zu Bremen 49: 331-332.

Melber, A.; Prüter, J.; Assing, V. \& Sprick, P. 1996: Erste Ergebnisse der Erfassung ausgewählter Wirbellosen-Gruppen in einer kleinen Vegetationsinsel auf den Panzerübungsflächen des NSG Lüneburger Heide (Heteroptera; Homoptera, Auchenorrhyncha; Coleoptera, Carabidae, Staphylinidae, Curculionoidea). - NNA-Berichte 1/96: 93-102.

Pope, R. D. 1977: Part 3: Coleoptera and Strepsiptera. - In: Kloet, G. S. \& Hincks, W. D.: A check list of British insects (Second Edition). Handbooks for the identification of British Insects, London 11 (3): xiv + 1-105.

Renner, K. 2001: Coleoptera Westfalica: Familia Staphylinidae, Subfamilia Aleocharinae). - Abhandlungen aus dem Westfälischen Museum für Naturkunde 63 (5): 1-214.

Rose, A. 2000: Die Kurzflügelkäfer der Sammlung F. und R. Struve von der Nordseeinsel Borkum (Coleoptera: Staphylinidae). - Entomologische Blätter 96 (2): 127-156

Roubal, J. 1931: Další nová Oxypoda ze Slovenska. Eine weitere neue Oxypoda aus der Slovakei. - Časopis Československé Společnosti Entomologické 28: 70-71.

SAhlberg, J. R. 1876: Enumeratio Coleopterorum brachypterorum Fenniae. I. Staphylinidae. - Acta Societatis pro Fauna Flora Fennica 1: 1-248.

Sharp, D. 1871: Notes on some British species of Oxypoda, with descriptions of new species. - The Transactions of the Entomological Society of London 1871: 187-192.

Smetana, A. 2004: Staphylinidae, subfamily Aleocharinae, pp. 353-494. - In: Löbl I. \& Smetana, A. (eds.): Catalogue of Palaearctic Coleoptera. II. Hydrophiloidea - Histeroidea - Staphylinoidea. - Stenstrup, Apollo Books: 942 pp.

Stephens, J. F. 1829: A systematic catalogue of British insects: being an attempt to arrange all the hitherto discovered indigenous insects in accordance with their natural affinities. - London: $416+388$ pp.

STEphens, J. F. 1832: Illustrations of British entomology. Mandibulata. Vol. V. - London: 1-240.

Vogel, J. 1978: Faunistisch bedeutsame und für die DDR neue Staphylinidae (Coleoptera) aus der Oberlausitz. - Abhandlungen und Berichte des Naturkundemuseums Görlitz 52 (8): 1-13.

Vogel, J. 1980: Bemerkenswerte und für die DDR neue Staphylinidae (Coleoptera) aus Thüringen. Entomologische Nachrichten 24: 34-40.

Vogel, J. \& Dunger, W. 1980: Untersuchungen über Struktur und Herkunft der Staphyliniden-Fauna (Coleoptera, Staphylinidae) einer Rasen-Wald-Catena in Thüringen (Leutratal bei Jena). - Abhandlungen und Berichte des Naturkundemuseums Görlitz 53 (3): 1-48.

Whitehead, P. F. 1996: The identity of Oxypoda brachyptera (Stephens) and O.tarda Sharp (Staphylinidae). - The Coleopterist 5 (1): 3-6.

\section{Author's address:}

Dr. Volker Assing

Gabelsbergerstr. 2

30163 Hannover, Germany

e-mail: vassing.hann@t-online.de

\section{Subject editor:}

Dr. L. ZerChe 